\title{
Biomass in the fuel mix of the Polish energy and heating sector
}

ABSTRACT: In 2008, the European Union adopted the climate and energy package. It foresees the three most important goals to achieve by 2020 in the field of energy: $20 \%$ reduction in greenhouse gas emissions, $20 \%$ share of energy from renewable sources in total energy consumption in the EU, $20 \%$ increase in EU energy efficiency. Therefore, individual countries were obliged to move away from fossil fuels for renewable energy production. Depending on the capabilities of each country and the development of renewable energy, various goals have been set for individual countries. For Poland, the share of RES energy in total energy consumption has been set at $15 \%$ (Directive 2009). The Polish energy policy until 2030 includes state strategies in the field of implementation of tasks and objectives in the area of energy resulting from the need to build national security and EU regulation. The challenges of the current national energy industry include increasing demand for energy and implementation of international commitments in the area of environmental and climate protection (Policy 2009). Contemporary domestic energy is characterized by a high share of fossil fuels, mainly coal, in the production of electricity and heat, and the different share of RES energy in individual technologies and energy sectors. Poland has significant natural resources, which are a source of biomass for energy purposes. Large energy units dominate in the national consumption of biomass while the share of heating plants is still insignificant (Olsztyńska 2018). The aim of the

$\triangle$ Corresponding Author: Ilona Olsztyńska; e-mail: Ilona.Olsztynska@sgs.com

1 SGS Polska, Product Development Manager Legal Regulated Certification (CORP); ORCID iD: 0000-00027952-8697; e-mail: Ilona.Olsztynska@sgs.com

2019. The Author(s). This is an open-access article distributed under the terms of the Creative Commons Attribution-ShareAlike International License (CC BY-SA 4.0, http://creativecommons.org/licenses/by-sa/4.0/), which permits use, distribution, and reproduction in any medium, provided that the Article is properly cited. 
article is to analyze, based on available data and own observations of the author, the share of biomass in the national energy and heat, as well as defining factors affecting the level of biomass use in the area of Polish power industry.

KEYWORDS: energy, heating, energy mix, energy policy of Poland, solid biofuels

\section{Introduction}

The energy policy of Poland until 2030 defines the following directions of shaping the national energy policy (Policy 2009):

^ Improving energy efficiency,

\ Increased security of fuel and energy supply,

$\downarrow$ Diversification of the structure of electricity generation through the introduction of nuclear energy,

$\downarrow$ Development of the use of renewable energy sources, including biofuels,

४ Development of competitive fuel and energy markets,

$\checkmark$ Reducing the impact of energy on the environment.

Individual directions are interrelated and interdependent, such as improving energy efficiency and limiting the increase in fuel and energy demand, reducing emissions and reducing the impact of energy on the environment, as well as the development of renewable energy sources and the share of biofuels in transport, and others. All these activities are aimed at increasing the country's energy security while maintaining the principles of sustainable development (Policy 2009).

Detailed tools have been defined in order to implement particular strategic directions of energy policy. These include, among others, legal regulations, regulations of the Energy Regulatory Office (URE), systemic support mechanisms, providing support from public funds, including European funds, and others (Policy 2009).

By 2030, the final consumption of electricity in Poland is expected to increase by $26 \%$ in the area of Industry, $64 \%$ in the Transport area and $90 \%$ in the Services area (Fig. 1).

An increase in energy consumption is associated with an increase in the consumption of individual energy carriers. In this area, an increase to the level of 2006 in the field of renewable energy sources (up to approx. 200\%), natural gas (up to approx. 40\%), crude oil and petroleum products (up to approx. 28\%) is anticipated (Fig. 2). In accordance with the assumptions of the Energy Policy of Poland by 2030, the increase in the consumption of individual carriers will be accompanied by a gradual departure from the demand for coal, including brown coal up to $23 \%$ and hard coal up to $16 \%$ in the 2030 perspective (Forecast 2009).

Poland has significant coal resources that act as a stabilizer of the country's energy security. This is important for other fossil fuels, which are largely imported to Poland - over 70\% gas and 


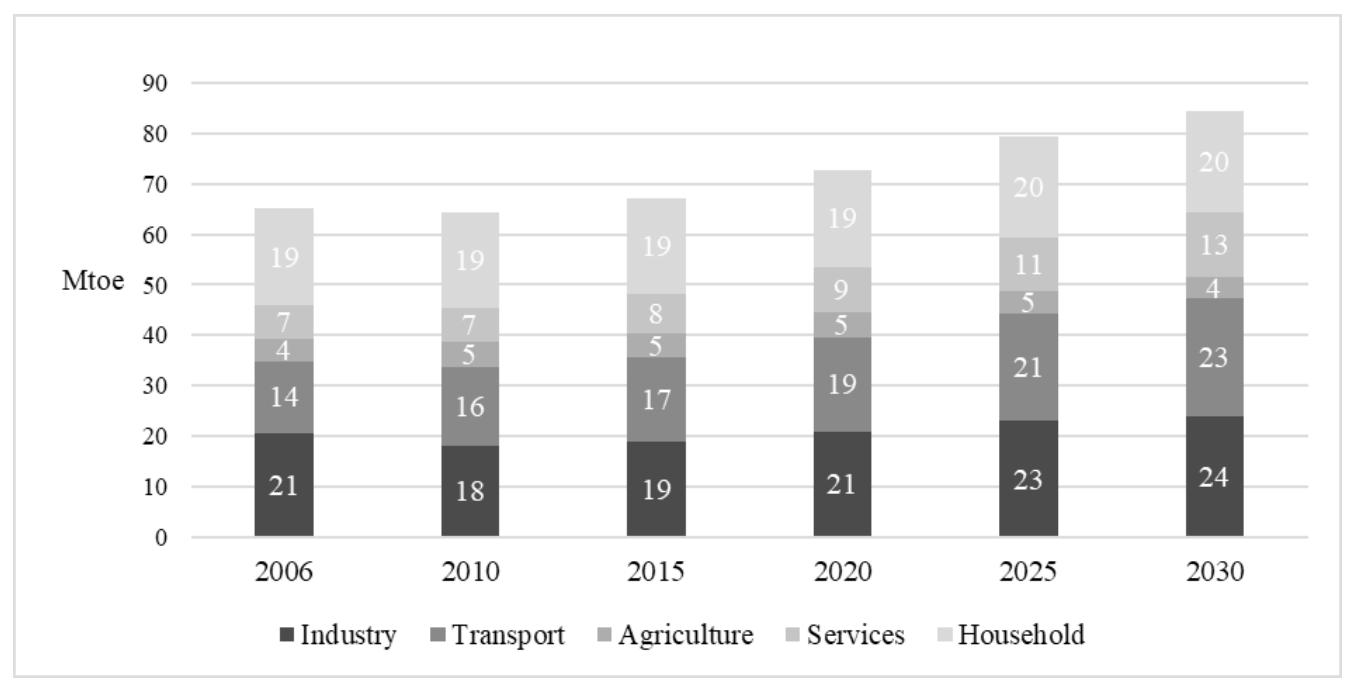

Fig. 1. Demand for final energy by sectors of the economy (Forecast 2009)

Rys. 1. Zapotrzebowanie na energię finalną w podziale na sektory gospodarki

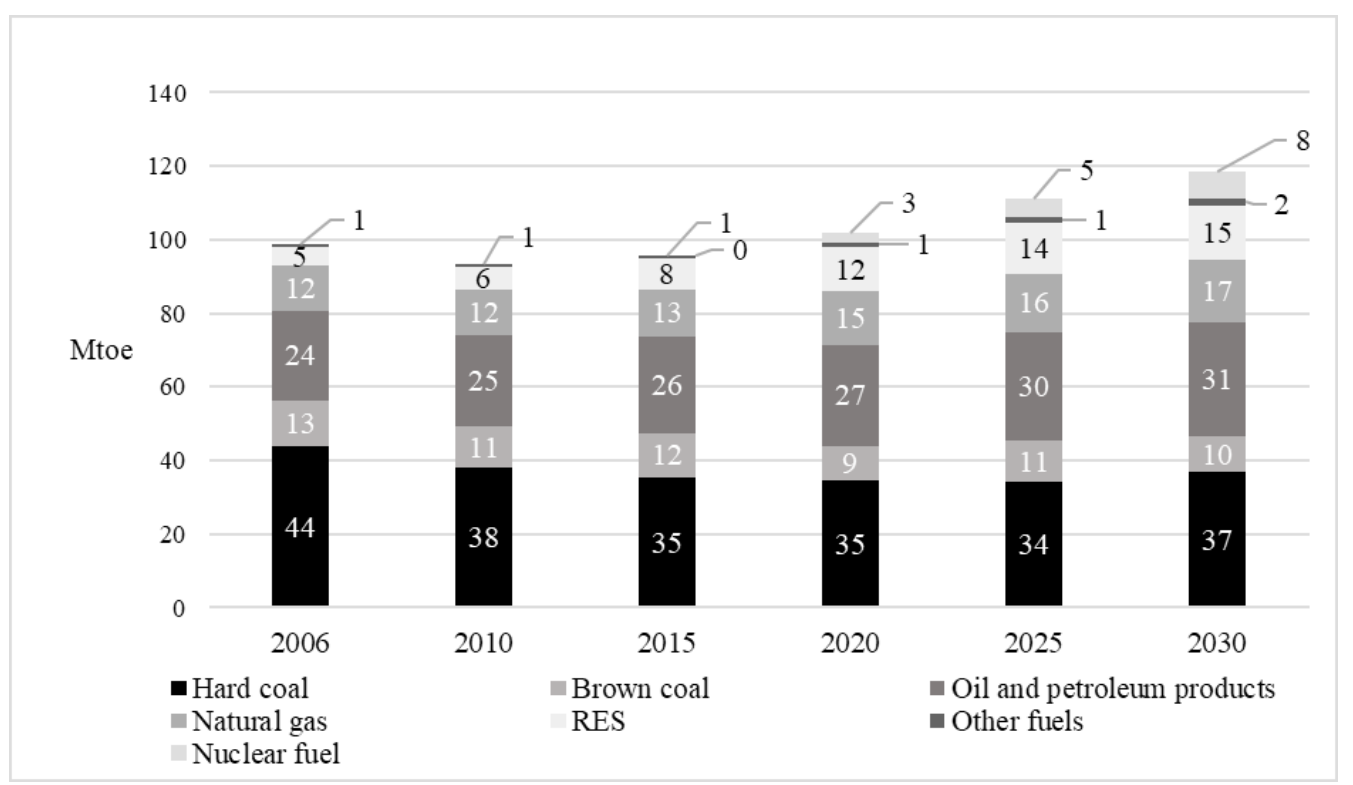

Fig. 2. Primary energy demand divided into energy carriers (Forecast 2009)

Rys 2. Zapotrzebowanie na energię pierwotną w podziale na nośniki

more than 95\% oil (Policy 2009). Nevertheless, coal deposits will gradually be depleted, and it is important to increase the share of renewable energy sources in the national energy mix, including using local renewable resources such as biomass (Forecast 2009). 
Energy from renewable energy sources is energy generated from renewable non-fossil sources, including: wind energy, solar radiation, aerothermal, geothermal, hydrothermal and ocean, hydropower, energy obtained from biomass, as well as from gas coming from landfills, sewage treatment plants and biological sources (biogas) (Directive 2009). In 2006, the development of renewable energy sources in Poland was planned and their development was expected in particular sectors of: electricity, heat and transport biofuels production. In this respect, it was expected to generate electricity from the following RES sources: wind, solid biomass, biogas, water and photovoltaics (Fig. 3), while for heat from: solid biomass, biogas, geothermal energy, solar energy (Fig. 4). In Poland's energy policy in the case of electricity production from RES, it was predicted that in 2020 the largest share would be wind (44\%), followed by biomass (33\%), biogas $(13 \%)$, water $(10 \%)$ and solar $(0.004 \%)$, while in 2030 respectively: wind $-45 \%$, biomass $-29 \%$, biogas $-17 \%$, water $-8 \%$, photovoltaics $-0.062 \%$ (Forecast 2009 ). In the field of district heating up to 2020, obtaining heat production from RES from the following energy carriers: biomass $-86 \%$, biogas $-8 \%$, geothermy $-4 \%$, solar $-2 \%$, while in 2030 : $83 \%$ from biomass, $11 \%$ from biogas, $5 \%$ from geothermal energy and $2 \%$ from solar energy was planned (Forecast 2009).

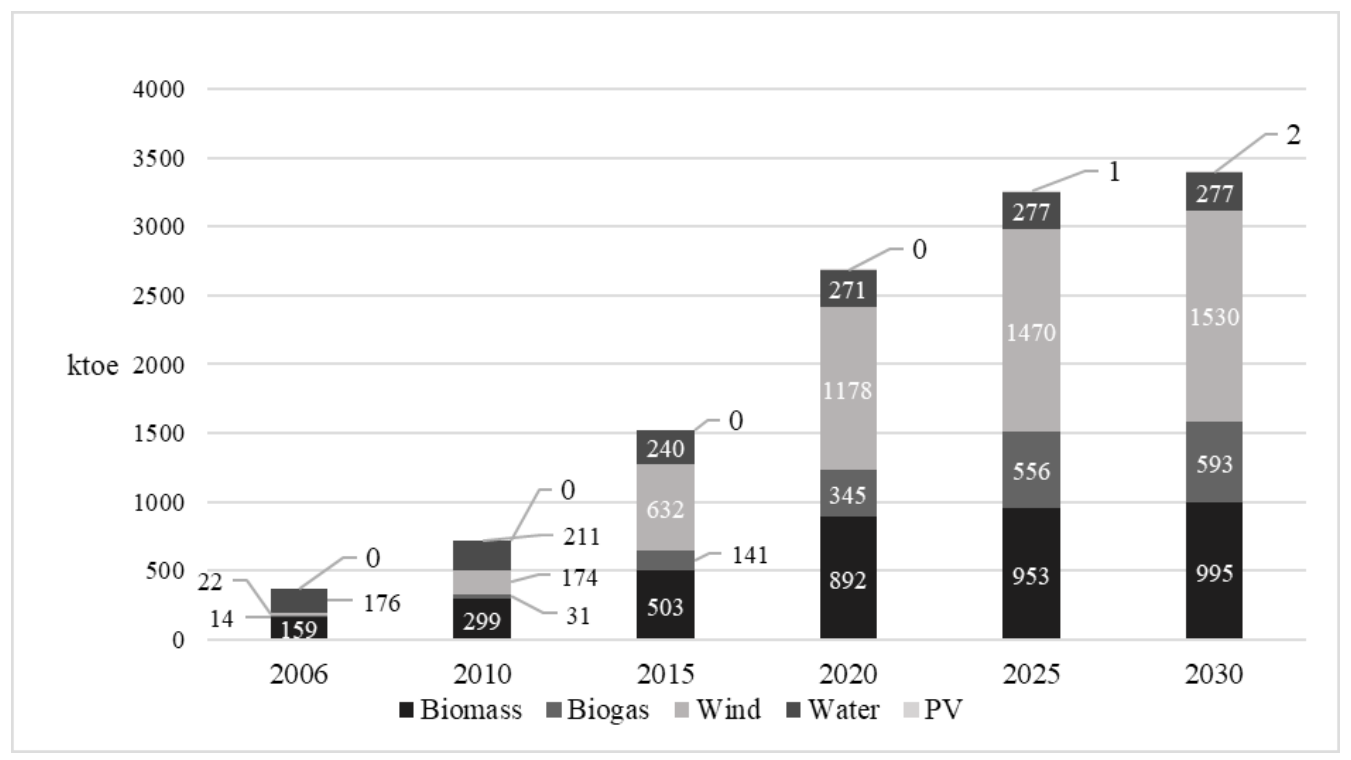

Fig. 3. Demand for gross final energy from RES for electricity (Forecast 2009)

Rys. 3. Zapotrzebowanie na energię finalną brutto z OZE dla energii elektrycznej 


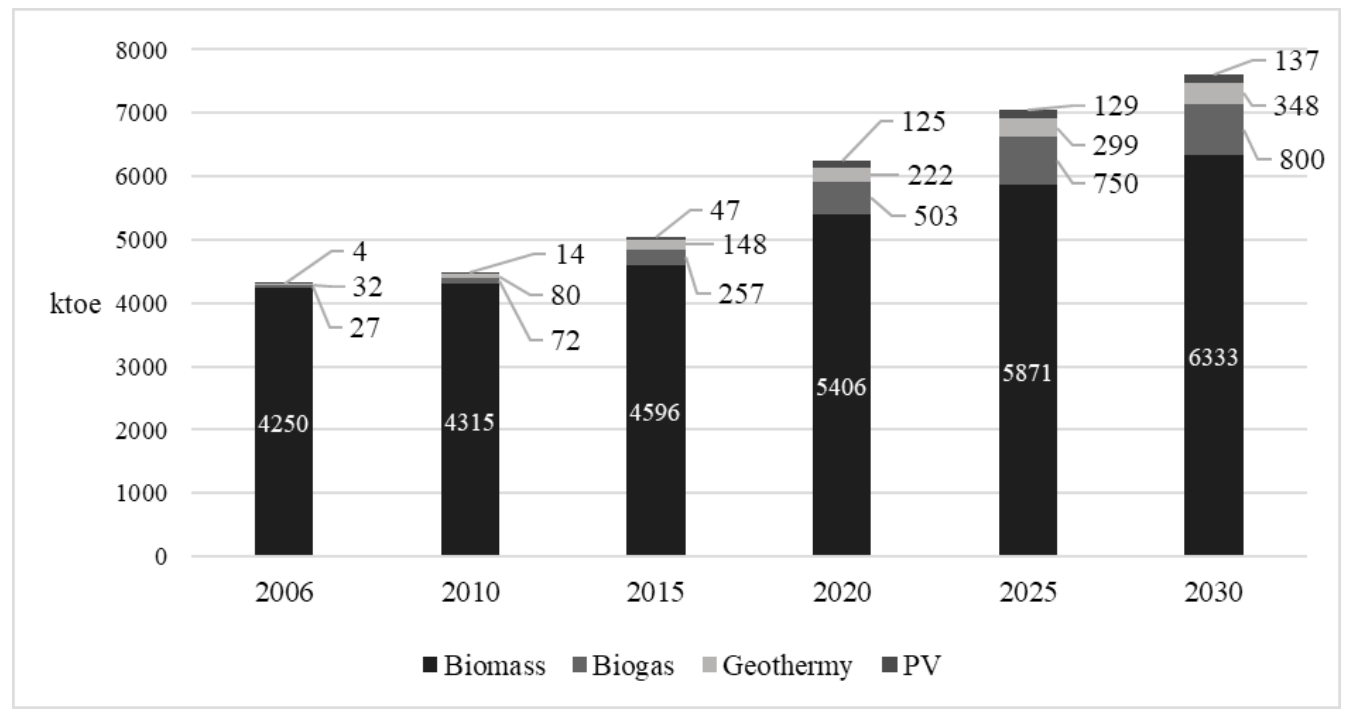

Fig. 4. Demand for gross final energy from RES for heating (Forecast 2009)

Rys. 4. Zapotrzebowanie na energię finalną brutto z OZE dla ciepłownictwa

\section{Biomass in Polish energy}

In terms of energy production in Poland, large energy groups dominate, such as PGE (38\% share in the generating sector in 2014), TAURON Group (11\%), ENEA (9\%), EDF Group (9\%), PAK (7\%), GDF Suez (6\%) and ENERGA (3.3\%) (IEA 2016). The structure of installed domestic electric power in Poland is dominated by hard coal power plants $-50.5 \%$ and brown coal $-19.1 \%$, followed by renewable energy plants $-14.4 \%$, gas and water power plants - each $5.1 \%$, as well as industrial power plants $-5.8 \%$ (PSE 2018).

Over the last 15 years, the installed capacity has been increasing as the National Energy System. The increase in installed capacity in 2018 to 2015 was 14\% (PSE 2018). The process of modernization and transformation of the Polish professional power industry is underway, including the change of energy carriers and gradual abandonment of fossil fuels for renewable energy sources (Fig. 5).

Electricity production in 2017 was based mainly on hard coal and brown coal, which together accounted for $78.4 \%$ (Forum-energii.eu). Energy from renewable energy sources accounted for $14.1 \%$, and its share was the largest share of energy from wind $(8.8 \%)$ and biomass (in total $3.1 \%$ ) (Fig. 6). In comparison to 2016, the production of hard coal (by $509 \mathrm{GWh}$ ) and biomass energy decreased (by 1109 GWh in dedicated units and by 550 GWh in co-firing units with coal) 


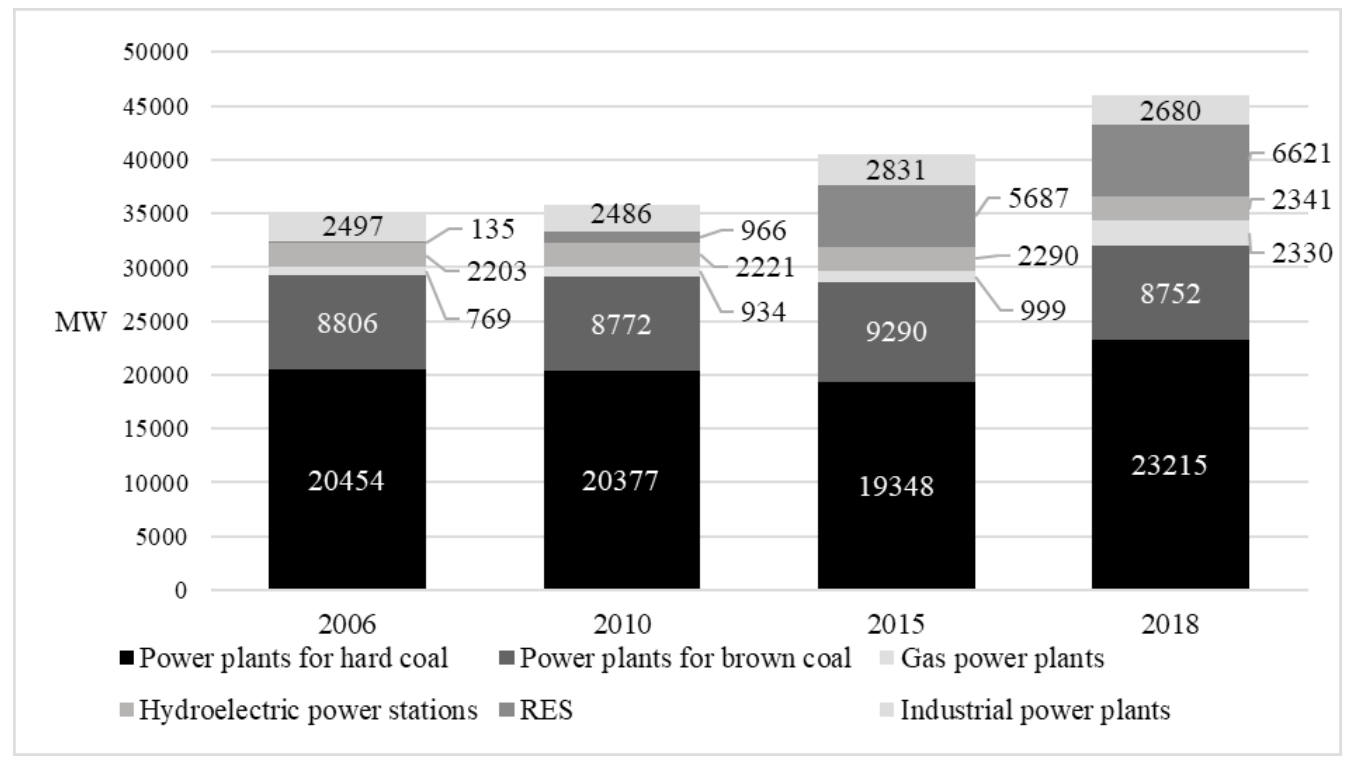

Fig. 5. Installed power in the National Power System [MW] (PSE 2018)

Rys. 5. Moc zainstalowana w Krajowym Systemie Energetycznym [MW]

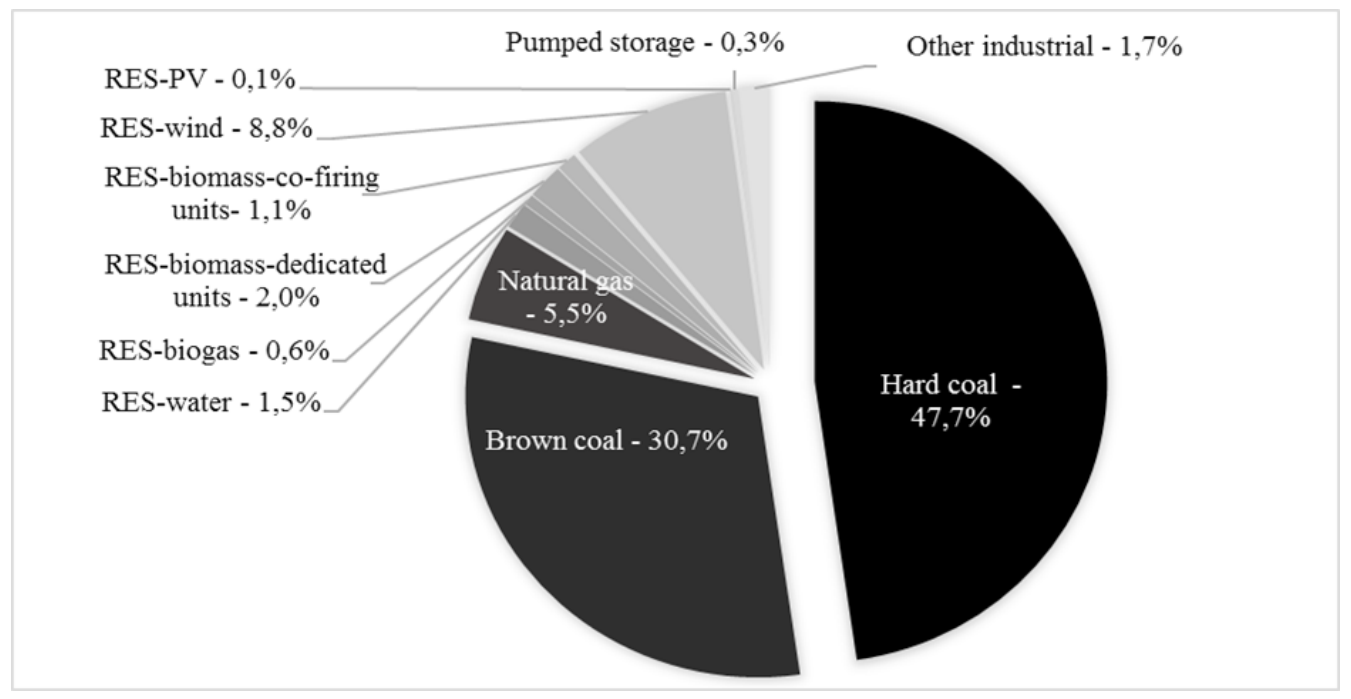

Fig. 6. Electricity production in 2017 [\%] (Forum-energii.eu)

Rys. 6. Produkcja energii elektrycznej w 2017 r. [\%]

(Forum-energii.eu). In 2017, electricity production increased mainly from wind (by $2317 \mathrm{GWh}$ ), but also from natural gas (by $1589 \mathrm{GWh}$ ), brown coal (by $1199 \mathrm{GWh}$ ), water (by $432 \mathrm{GWh}$ ), biogas (by $76 \mathrm{GWh}$ ) and photovoltaics (by $37 \mathrm{GWh}$ ) (Forum-energii.eu). 
According to data published by the Energy Regulatory Office (URE), the installed capacity in Poland in the field of renewable energy sources at the end of the first quarter of 2019 amounted to $8717,72 \mathrm{MW}$. The installed capacity of RES was in the following division into sources: wind (67\%), biomass (17\%), hydro-energy (11\%), biogas (3\%), PV (2\%) (Fig. 7). This data concerns installations that have obtained a license for the production of electricity, an entry in the register of regulated activity kept by the President of the Energy Regulatory Office (register of energy producers in a small installation), and an entry in the register of regulated activity of the General Director of the National Agricultural Support Center agricultural biogas) and microinstallations, as well as applications for issuing certificates of origin (URE 2019).

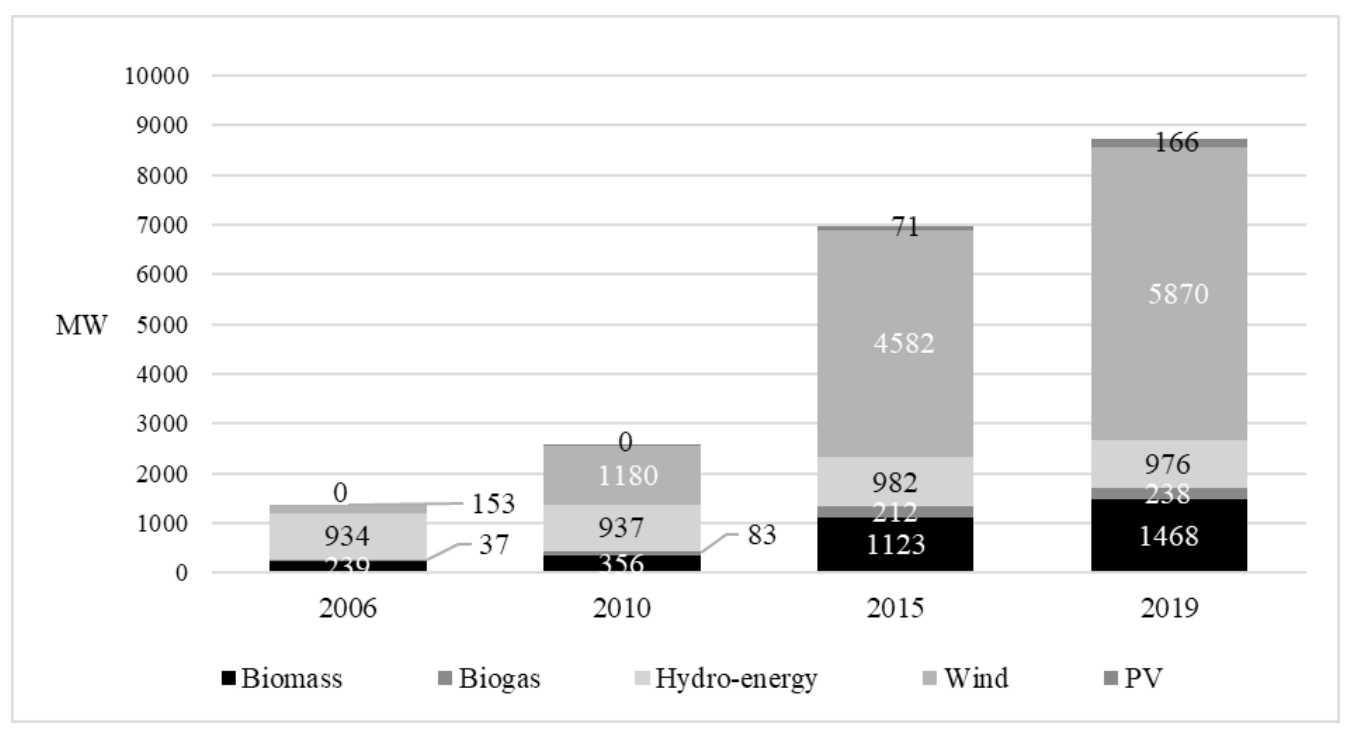

Fig. 7. Installed RES power - state on 2019-03-31 [MW] (URE 2019)

Rys. 7. Moc zainstalowana OZE - stan na 31.03.2019 r. [MW]

The energy obtained from biomass in the combustion process is treated as zero-emission energy (Kobize 2012). This means that carbon dioxide is released into the atmosphere in the combustion process to produce bioenergy, the amount of which corresponds approximately to the amount of carbon dioxide absorbed by the organic plant matter in the process of its growth (Molo 2016).

Energy from biomass in Poland is generated in the combustion process in 24 dedicated generating units with a total capacity of $629 \mathrm{MW}$ (2014) (IEA 2016). Since 2005, a steady increase in the production of energy produced from biomass has been observed in Poland $(2008-3.2 \mathrm{TWh}$, 2012 - 9.54 TWh) (Czopek 2014). It is also estimated that in 2011 about 64,645 PJ of biomass was delivered to Polish power plants (Czopek 2014). In the years 2011-2012, biomass was used mainly by energy groups: PGE, EDF and the Tauron Group as well as Energa and Enea, and after 2012 its consumption also increased in GDF SUEZ and in ZE PAK (Uliasz-Bocheńczyk 2015). 
During this period biomass was co-firing with coal both in power plants and combined heat and power plants, and its consumption amounted to approximately 70,035,710 GJ for energy plants using basic coal as the basic fuel and 11,225,878 GJ for brown coal plants (Uliasz-Bocheńczyk 2015).

At present, the greatest demand for solid biofuels is on the part of the ENEA energy group, which produces energy from RES in the largest biomass power plant in Połaniec and in the heat and power plant in Białystok.

The share of biomass in the Polish RES mix systematically increased in 2005-2012, when energy from biomass accounted for up to 60\% of energy from RES (PSE 2018). In 2016-2017, the amount of electricity produced from biomass decreased, and its share accounted for $35 \%$ and 27\% (PSE 2018). At the same time, the amount of energy from biomass in the RES mix of the European Union was about 45\% (Eurostat 2018).

In the European Union there is a steady increase in the amount of energy coming from the combustion of biomass, including wood and solid biofuels. This increase was 5\% in 2015 and $2 \%$ in 2016 (Eurostat 2018). The situation is different in Poland, where the amount of biomass consumption for energy purposes has been falling since 2013 and in 2016 this drop was $20 \%$, and in $2017-19 \%$ compared to the previous year (PSE 2018).

Despite the decline in biomass consumption for energy purposes, the amount of energy from renewable energy in 2016-2017 increased. This increase was related to energy production from wind: an increase of $16 \%$ and $18 \%$, hydro energy: an increase of $17 \%$ and $20 \%$, energy from photovoltaics: an increase of $118 \%$ and $30 \%$ (Fig. 8 ).

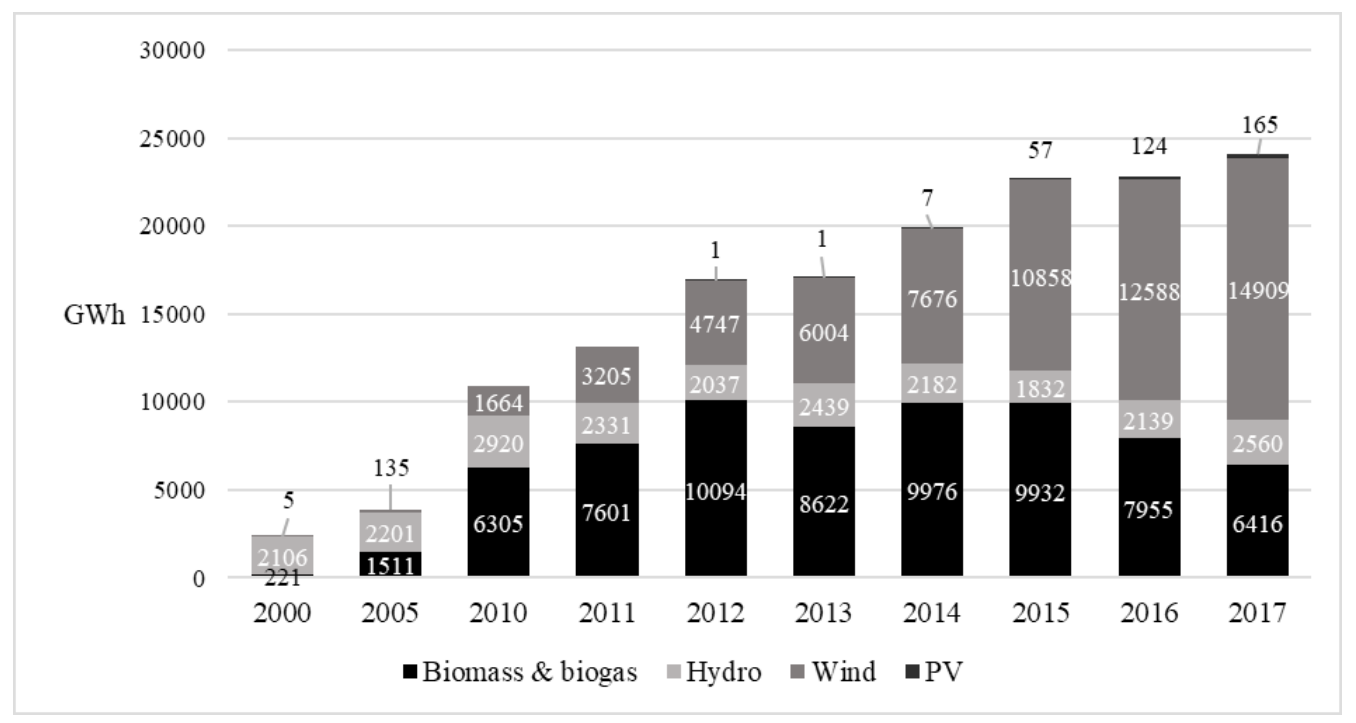

Fig. 8. Production of energy from RES in Poland (Open data 2019)

Rys. 8. Produkcja energii z OZE w Polsce 
The share of biomass in the RES energy mix in Poland has been falling since 2013 in relation to energy generated mainly from wind. The share of energy from biomass in the national RES mix in 2016 was $35 \%$, and in $2017-27 \%$. In the same period, the share of wind energy in the RES mix in 2016 was $55 \%$, and in $2017-62 \%$ of total energy produced from RES in Poland (PSE 2018).

Several factors contributed to the decrease in demand for biomass on the Polish energy market. Production units co-firing biomass with coal, and in addition to biomass units, also having an installation for coal combustion, decided to only burn coal (Olsztyńska 2017). This was due to the decrease in coal prices on the domestic market, whose quotations from October 2016 on the commodity exchange on average amounted to around PLN 9/GJ. At the same time, the market price of biomass was at the level of PLN 12-19/GJ (Olsztyńska 2017). The homogeneity of coal and its high calorific value, its easy storage, and above all the lack of the need to collect complicated documentation confirming the origin of this fuel, additionally encouraged the power industry to consume coal instead of biomass for energy production (Olsztyńska 2017).

Another factor having an impact on reducing the demand for biomass was the lowering of the value of certificates of origin, so-called 'Green certificates' listed on Towarowa Giełda Energii SA (TGE) (Olsztyńska 2017). Green certificates for producing energy from biomass and wind are part of the support system created in 2005 to strengthen the development of electricity production from renewable sources (Olsztyńska 2017). These certificates are a property right arising after registration in the Register of Certificates of Origin issued by the President of the Energy Regulatory Office (URE). These certificates are obtained by the generating units after the submission of relevant declarations regarding the production of renewable energy to the President of the Energy Regulatory Office (Olsztyńska 2017). The drop in prices of certificates of origin on the Polish Power Exchange since 2013, which has intensified since August 2016, was caused by their oversupply in the market, which resulted from a higher rate of renewable energy production (followed by granting green certificates) to the rate of redemption of certificates obtained from its production (Olsztyńska 2017). In 2016, green certificates for more than 25 TWh of RES energy were traded on the stock exchange, that is more than annual RES energy production in Poland (Olsztyńska 2017).

Factors affecting this oversupply were: providing the "entire" certificate of origin for energy generated in installations co-burning biomass with coal, as well as the intensive development of wind energy (Olsztyńska 2016). The "unrivaled" cost of biomass combustion in relation to the cost of coal combustion has stopped the production of energy from biomass. According to the energetics, biomass burning for energy purposes is "profitable" at the price of green certificates at the level of about 70 PLN/MWh (Olsztyńska 2017). Legislative changes, including subsequent amendments to the RES Act concerning, among others, half of the certificate for energy produced in co-combustion of biomass with coal, as well as the reduction in the value of the substitution fee, increased the prices of green certificates on TGE (Fig. 9).

The increase in prices of $\mathrm{CO}_{2}$ emission allowances recorded since 2018 also had a significant impact on the increase in the demand for biomass. 


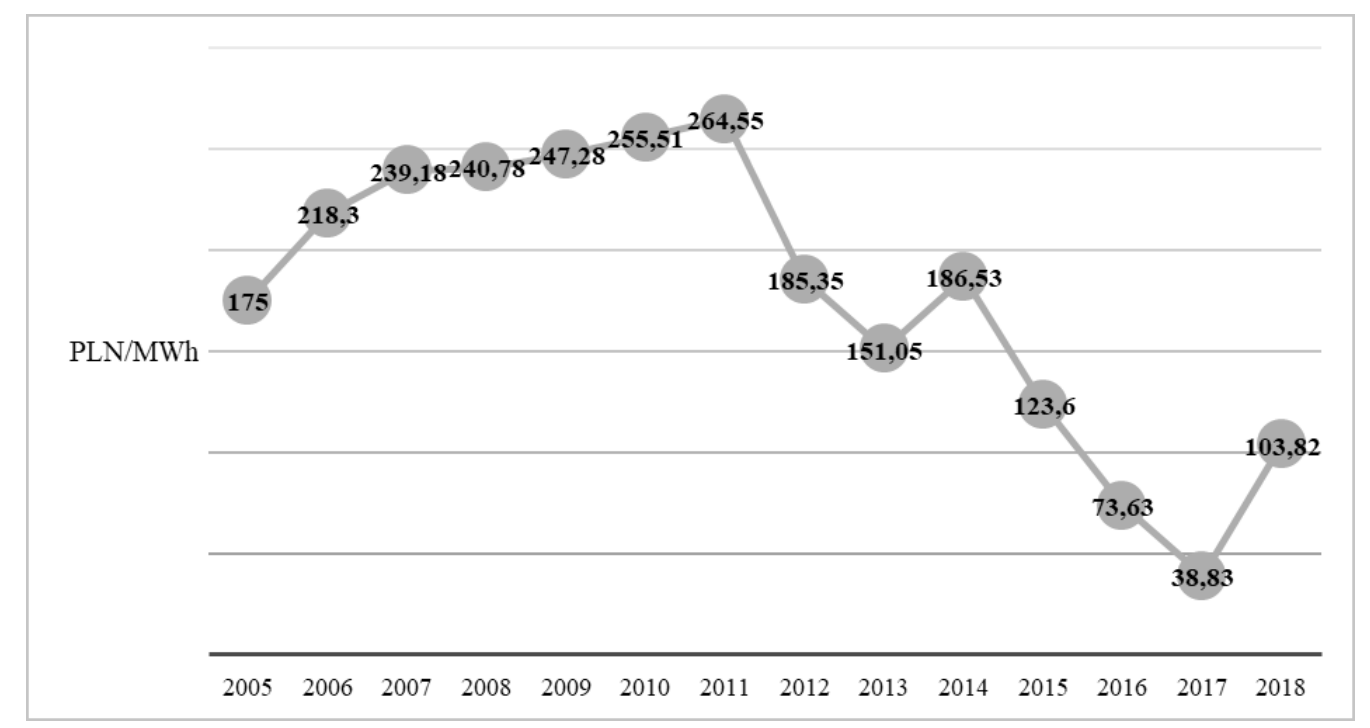

Fig. 9. Quotations of green certificates on the TGE in 2005-2018 (TGE 2019)

Rys. 9. Notowania zielonych certyfikatów na TGE w latach 2005-2018

\section{Biomass in the Polish heating industry}

The total thermal power installed by licensed heat generators in 2017 was $54,911.8 \mathrm{MW}$, and the available power was 53,639.5 MW (URE 2018). The distribution of heat generating units in Poland is not even, and their greatest concentration is located in the Śląskie Province (12.6\%), and the least in the Lubuskie Province (2.6\%) (URE 2018).

Small installations of up to $50 \mathrm{MW}-53.8 \%$ in 2017 (URE 2018) prevail in the domestic heating industry. Only $30 \%$ of licensed heat generators generate them in the cogeneration process, and the amount of such heat in 2017 was about $61 \%$ (URE 2018).

Domestic fossil fuels dominate in domestic heating, including $72.2 \%$ of hard coal, $8.5 \%$ of natural gas and $1.6 \%$ of brown coal (URE 2018). In 2017, the share of energy from RES in the domestic heating sector accounted for only $7.6 \%$ and it was mainly energy from biomass (Fig. 10).

The Polish heating industry has improved its technical indicators over the past 15 years, especially in terms of production efficiency, but unfortunately the efficiency of transmission is still unchanged (URE 2018). There is also a decrease in the level of harmful substances emission to the atmosphere by more than $17 \%$, mainly dust, sulfur dioxide and nitrogen oxides, including the reduction of $\mathrm{CO}_{2}$ emission (URE 2018).

108 


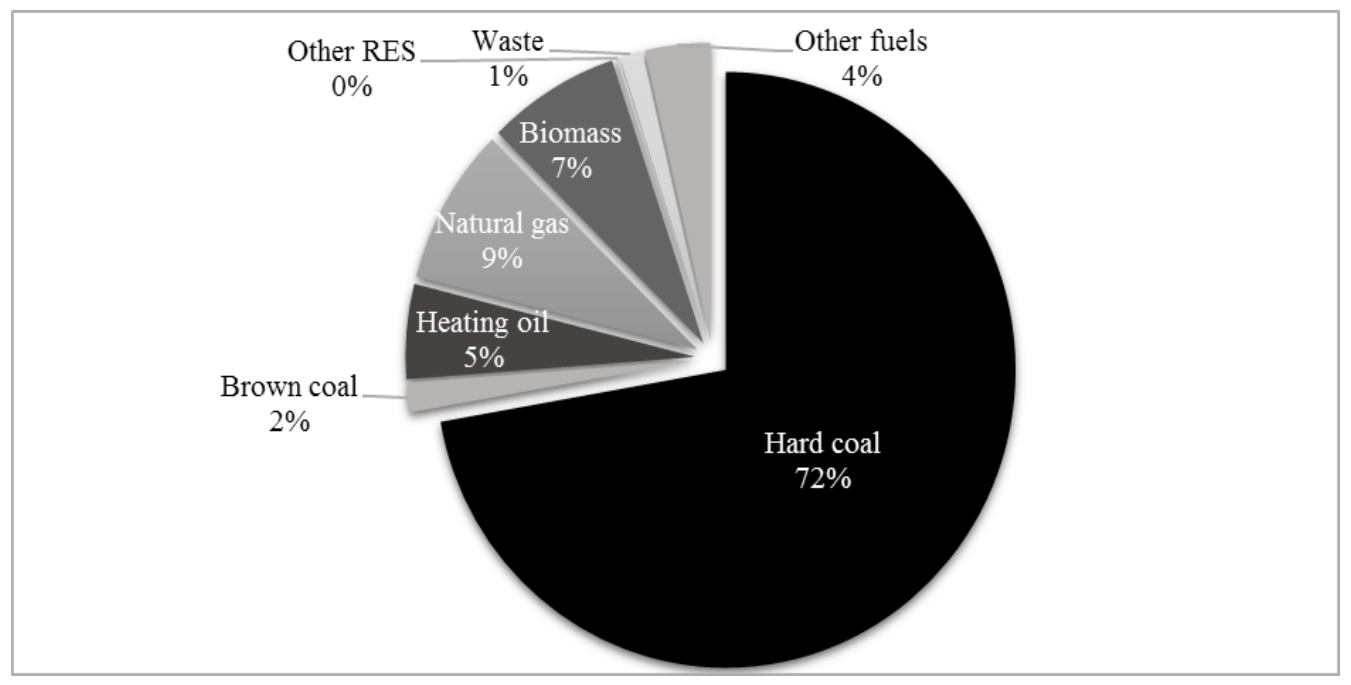

Fig. 10. Share of particular fuels in heat production in Poland in 2017 (URE 2018)

Rys. 10. Udział poszczególnych paliw w produkcji ciepła w Polsce w 2017 r.

In the area of Polish heat sector, no support certificates for generating RES heat are granted. The only support for heating was provided for the production of energy in combination with heat in cogeneration systems, this system was in force until the end of 2018.

Currently, there is no more detailed data on the consumption of biomass for heating purposes, due to the significant dispersion of heating plants and the lack of a license requirement for heat generation for units below 5 MW (IEA 2016).

At the present time, many heating facilities undergo modernization to meet the emission requirements set out in the Directive on Medium Fuel Combustion Sources (MCP) and the Industrial Emissions Directive (IED). Both directives have been implemented into the Polish legislation.

Under the MCP Directive, in units of nominal thermal power from $1 \mathrm{MW}$ to $50 \mathrm{MW}$, regardless of the type of fuel they use, the level of pollutants emitted to air $\left(\mathrm{SO}_{2}, \mathrm{NO}_{\mathrm{x}}\right.$ and dust $)$ must be limited to the level specified in the Directive for 2025 and 2030 (Directive 2015).

Pursuant to the IED Directive for combustion plants above $50 \mathrm{MW}$, the requirements regarding emissions to the environment (air, water and ground) have been defined, which should be achieved by power combustion plants by 2023 (Directive 2010).

In the field of renewable heat production, many changes in the Polish heating industry will take place in the coming years. From 2021, pursuant to the Directive of the European Parliament and the Council 2018/2001 of December 11, 2018 on the promotion of the use of energy from renewable sources (RED II), new targets for energy production from RES for the entire Union and member states will be introduced. The new guidelines will introduce, among others, requirements for increasing the role of renewable energy in heating and cooling, i.e. an increase of $1.3 \%$ in the share of energy from RES in the heating and cooling sector (annual average calculated for 
periods 2021-2025 and 2026-2030) (Directive 2018). A new way of calculating the final gross final consumption of energy in individual Member States will also be introduced, which will require the aggregation of: (a) the final gross electricity consumption from renewable sources; (b) gross final consumption of energy from renewable sources in the heating and cooling sector; and (c) final consumption of energy from renewable sources in the transport sector (Directive 2018).

\section{Legal regulations in the area of biomass}

Solid biofuels include organic, non-fossil substances of biological origin that can be used as a fuel for the production of heat or for the production of electricity. The basic biofuel is firewood occurring in the form of logs and round logs, wood chips and briquettes, pellets and wastes from forestry in the form of undersized wood: branches, poles, shrubs, brushwood, carp, as well as waste from the wood industry (chips, sawdust) and paper (black lye). A separate group consists of fuels from plantations intended for energy purposes (fast growing trees, dicotyledonous perennials, perennial grasses, grains cultivated for energy purposes) and organic residues from agriculture and horticulture (eg waste from gardening production, animal droppings, straw). The group of solid biofuels also includes: charcoal, understood as solid residues of destructive distillation and pyrolysis of wood and other plant substances (GUS 2017).

The scope of biomass fuel is defined in Directive 2009/28 / EC of the European Parliament and of the Council of 23 April 2009 on the promotion of the use of energy from renewable sources, amending and subsequently repealing Directives 2001/77 / EC and 2003/30 / EC (RED) as well as in national legal regulations. As defined in the RED directive, biomass is a biodegradable portion of products, waste or residues of biological origin from agriculture (including vegetal and animal substances), forestry and related industries, including fisheries and aquaculture, as well as the biodegradable fraction of industrial waste and urban areas (Directive 2009).

In the Polish legislation, its definition was introduced in the Act on renewable energy sources of February 20, 2015 (in short, the RES Act). Its current wording is: Biodegradable part of products, waste or residues of biological origin from agriculture, including plant and animal substances, forestry and related industries, including fisheries and aquaculture, processed biomass, in particular in the form of briquettes, pellets, of the torrefaction and biocarbon, as well as the biodegradable fraction of industrial or municipal waste of plant or animal origin, including waste from waste treatment installations and waste from water treatment and wastewater treatment, in particular sewage sludge, in accordance with the provisions on waste in the field of eligibility of part of energy recovered from waste thermal treatment (Act 2015).

In addition, the provisions contained in the definition of biomass specify other legal provisions, including the information of the President of the Energy Regulatory Office. 
Pursuant to the provisions of the Act on Renewable Energy Sources, the certificate of origin does not apply to the part of electricity to which it is produced (Act 2018):

$\downarrow$ wood other than energy wood and wholesome cereals were used;

$\downarrow$ fossil fuels or fuels resulting from their processing were used;

$\downarrow$ polluted biomass was used to increase its calorific value;

$\checkmark$ the minimum share of local biomass in the total biomass mass has not been met.

Biomass from the agricultural sector and related branches has been defined as "biomass of agricultural origin", which is biomass from energy crops, as well as waste or residues from agricultural production and industry processing its products (Act 2018). The requirement to keep the minimum share of biomass of agricultural origin in the total biomass mass used for energy purposes, which is (Act 2018), was also introduced:

$\checkmark 85 \%$ - for multi-fuel combustion installations and dedicated multi-fuel combustion plants with an installed electric power of more than $5 \mathrm{MW}$;

$\downarrow 10 \%$ - for dedicated biomass burning installations and hybrid systems with installed electric power higher than $20 \mathrm{MW}$.

This share can be changed by the Minister competent for energy through the regulation (Act 2018).

Biomass from forestry and related sectors must meet the requirements of the definition of "energy wood", which means: wood raw material, which due to its qualitative and dimensional characteristics has a reduced technical and utilitarian value preventing its industrial use, as well as wood raw material being biomass of agricultural origin (Act 2018). Due to the lack of regulation in the field of detailed quality-energy characteristics of wood, the requirement to document the origin of wood biomass according to the criterion of full-value timber (Note 2017) was restored as of July 1,2018, and later the energy producers are obliged to: follow the necessity first and foremost obtaining confirmation that the wood material used meets the statutory requirements for the definition of energy wood, i.e. that it has a reduced technical and functional value preventing its industrial use due to its qualitative and dimensional characteristics (Information 2018).

Therefore, in the field of forest biomass documentation, power generators are guided by guidelines for energy wood (Act 2018), as well as full-value timber with the Regulation of the Minister of Economy on, among others, the detailed scope of obligations to obtain and submit certificates of origin for redemption (Olsztyńska 2018). The definition of "wholesome wood" introduced by the Regulation of the Minister of Economy of October 18, 2012 on the detailed scope of obligations to obtain and submit certificates of origin for redemption, payment of a substitute fee, purchase of electricity and heat generated in renewable energy sources and the obligation to confirm data on the amount of energy electricity produced in a renewable energy source, means timber meeting the quality requirements specified in the standards specifying requirements and tests for large-sized hardwood, large-sized coniferous wood and medium-dimensional timber for groups marked S1, S2 and S3 and wood material resulting from the process of deliberate fragmentation of this wood (Regulation 2012). This means that wood assortments that can potentially be used for energy purposes and serve as a material for biomass production are: firewood (S4), thin and branch wood (M1, M2) and rootwood, which can be delivered to the power industry in the form of chips or roll (Olsztyńska 2018). 
National legal regulations also define quality requirements for biomass for energy purposes. The Regulation of the Minister of Environment from April 22, 2011 on emission standards for installations contains a requirement that allows biomass for energy purposes to be classified cork and wood, but without the waste timber, which may include halogenorganic compounds or heavy metals resulting from the treatment of wood preservatives or coating, and which includes, in particular, wood from construction and demolition waste. Biomass for energy purposes can't also be contaminated with peat fractions and coal fossils of biomass materials (Regulation 2008). In view of the above, the use of biomass for energy purposes requires its assessment in terms of sources of origin as well as possible contamination with chemical substances and other non-biomass substances (Olsztyńska 2018).

The current definition of biomass also allows the use of processed fuels in the form of torrefat and biochar as a biofuel (Act 2015). The RES Act contains a definition of both torrefat and biochar. Biochar is defined as high-energy solid fuel with a calorific value of not less than $21 \mathrm{GJ} / \mathrm{t}$ produced in the process of thermal processing of solid substances of plant or animal origin, biodegradable and derived from: a) products, waste and residues from agricultural and forestry production and the processing industry their products, b) parts of waste other than those referred to in point a, which are biodegradable, excluding waste from waste treatment installations and waste from water treatment and wastewater treatment within the meaning of waste legislation, this process takes place at a temperature of $320-700^{\circ} \mathrm{C}$ in an anaerobic atmosphere or with a significant oxygen deficiency and with near atmospheric pressure without the use of catalysts or foreign substances (Act 2018).

Torrefat was defined as a high-energy solid fuel with a calorific value of not less than $21 \mathrm{GJ} / \mathrm{t}$ produced in the process of thermal processing of solid substances of plant or animal origin, biodegradable and derived from: a) products, waste and residues from agricultural and forestry production and the processing industry their products, $b$ ) parts of waste other than those referred to in point $\mathrm{a}$, which are biodegradable, excluding waste from waste treatment installations and waste from water treatment and wastewater treatment within the meaning of waste legislation, this process taking place at a temperature between $200-320^{\circ} \mathrm{C}$ in an anaerobic atmosphere or with significant oxygen deficiency and at close to atmospheric pressure without the use of catalysts or foreign substances (Act 2018).

The carbonization process, like tarification, is one of the ways to valorize biomass parameters in terms of increasing the calorific value, reducing volatile matter and moisture content, while ensuring stable characteristics of the resulting fuel. At the same time, this process produces heat from gas combustion (Mirowski et al. 2019). Until now, both torrefat and biochar have been a little-known product produced more for scientific and experimental purposes than commercial ones. Including them in the group of substrates that meet the definition of biomass for energy purposes will affect their supply on the Polish market, which is already beginning to be noticeable.

From 2021, according to Directive 2018/2001 of the European Parliament and of the Council of December 11, 2018 on the promotion of the use of energy from renewable sources (RED II), the sustainability criteria and reduction of greenhouse gas emissions will also cover biomass and biomass fuels used for energy purposes. These criteria were established separately for fuels 
from agricultural biomass as well as for fuels from forest biomass (Directive 2018). Energy from biofuels, bioliquids and biomass fuels will only be taken into account provided it meets the sustainability criteria and criteria for reducing greenhouse gas emissions (Directive 2018). The criteria for sustainable development and reduction of greenhouse gas emissions will apply irrespective of the geographical origin of the biomass and will apply to installations producing: electricity, heat and cold or fuels with a total thermal power of at least $20 \mathrm{MW}$ (for solid fuels from biomass) and energy electricity, heat and cold or fuels with a total rated thermal input of at least 2 MW (for gas fuels from biomass) (Directive 2018).

\section{National biomass resources}

The first Strategy for the Development of Renewable Energy Sources for Poland assumed the development of primarily energy based on solid biofuels. This was due to the fact that Poland is a country with great natural potential. The first valorization of domestic resources indicated the potential of biomass mainly in the form of wood and straw. It was estimated then that the annual amount of technically feasible biofuels for energy purposes is about 465.1 PJ (Strategy 2000). The scope of this potential includes surplus biomass obtained: in agriculture - about $195 \mathrm{PJ}$, in forestry $-158.6 \mathrm{PJ}$, in orchards $-57.6 \mathrm{PJ}$ and wood waste from the wood industry $-53.9 \mathrm{PJ}$ (EC BREC 2000).

Later studies confirmed the high abundance of domestic biomass sources and the possibility of using them for energy purposes, including the production of electricity and heat. Modern estimates indicate the technical potential of straw for energy purposes at 10,113,199-11,471,486 tons (Hryniewicz and Grzybek 2017). The estimated share of wood constituting the theoretical basis of the raw material for energy purposes in forests is currently about $18.5 \%$ of wood harvested in the State Forests and about $23.0 \%$ of wood thickness obtained in private forests (Zajączkowski 2013). The technical potential of wood biomass in the State Forests was determined at the level of: $2011-5.99$ million $\mathrm{m}^{3}, 2021-6.82$ million $\mathrm{m}^{3}$ and $2031-7.53$ million $\mathrm{m}^{3}$, and for private forests: 2011 respectively. -0.91 million $\mathrm{m}^{3}, 2021-1.12$ million $\mathrm{m}^{3}, 2031-$ 1.38 million $\mathrm{m}^{3}$ (Zajączkowski 2013).

The actual availability of straw as well as wood for energy purposes may in practice be lower. In the case of straw, some of it is crushed to fertilize arable fields naturally. However, not all firewood and not all logging residues in forests can be allocated for energy purposes, due to: the need to ensure the demand for firewood for the population, leaving part of the thicknesses and lumber in the forest for the protection of forest ecosystems, or to meet the requirements set out in the principles of forest certification (Zajączkowski 2013).

An alternative source of wood biomass for energy purposes in Poland is the cultivation of fast-growing woody plants. In 2010, plantation energy crops in Poland occupied an area of only about 10.2 thousand ha, which in relation to the total area of arable land (UAA) in the country 
constituted about $0.06 \%$ (Szczukowski and Stolarski 2013). The dominant species in the cultivation were: shrub willow -6160 ha, poplar -648 ha, birch and alder -23 ha, giant Miscanthus 1833 ha, other perennial grasses - 1364 ha, reed canary - 53 ha and Pennsylvanian mallow 122 ha (Szczukowski and Stolarski 2013). According to estimates, in 2010 it was potentially possible to obtain about 200 thousand $\mathrm{m}^{3}$ of wood from the fast-growing tree plantation, which is about $1 \%$ of the total supply of energy wood in Poland (Ratajczak and Bidziński 2013). Unfortunately, the farmers' interest in establishing perennial crops remains low, which is caused by: no additional subsidies for energy crops, high costs of establishing plantations, mistakes made when establishing and running plantations, high costs of purchasing planting and harvesting machines, lack of stable biomass market, long a period of waiting for the first revenues, unwillingness to take many years of risk with the possibility of obtaining higher revenues from other production (Szczukowski and Stolarski 2013).

In 2010, it was determined that biomass from the wood industry and constituting a by-product of wood, wood materials and products processing was 5.3 million $\mathrm{m}^{3}$ (including $44 \%$ from the sawmill industry and 27\% from furniture) (Ratajczak and Bidziński 2013). This amount accounted for approximately $34.6 \%$ of the total supply of wood biomass of wood origin for energy purposes in Poland (Ratajczak and Bidziński 2013). By-products from wood processing can be of various forms and sizes (Ratajczak and Bidziński 2013).

According to forecasts, the quantitative potential of wood biomass for energy purposes is to increase its share in the wood industry sector by up to $16-26 \%$ in subsequent years (Ratajczak and Bidziński 2013). The forecast growth depends, however, on the economic situation for wood products and the demand for by-products from plate and cellulose plants (Olsztyńska 2018).

According to experts, in the future one can expect an increase in the use of wood biomass for own energy purposes in the wood sector, as well as a greater interest in biomass by individual customers, as well as municipal entities and public utilities (Ratajczak and Bidziński 2013).

Due to legal regulations regarding the quality requirements for biomass, obtaining wood biomass from municipal utilities is almost impossible (Olsztyńska 2018), and the supply of post-use wood for energy purposes in 2015 was estimated at 4.5-4.7 million $\mathrm{m}^{3}$ of wood biomass (Ratajczak and Bidziński 2013).

According to research by the Wood Technology Institute, the consumption of wood biomass alone for energy purposes in 2010 in Poland amounted to approximately 14.5 million $\mathrm{m}^{3}$, including 3.8 million $\mathrm{m}^{3}$ in professional power engineering, 2.1 million $\mathrm{m}^{3}$ in industrial power engineering, by individual recipients -8.6 million $\mathrm{m}^{3}$ (Ratajczak and Bidziński 2013). 


\section{Summary}

Domestic energy is based mainly on fossil energy sources. The structure of installed domestic electric power in Poland is dominated by hard coal of 50.5\%, and brown coal 19.1\% (PSE 2018 ), while in domestic heat production: hard coal $72.2 \%$, natural gas $8.5 \%$ and brown coal $1.6 \%$ (URE 2018). The share of other energy carriers, including renewable energy sources, has been increasing for several years. In 2017, electricity from renewable energy sources accounted for $14.1 \%$ (PSE 2018), and in the heating sector only 7.6\% (URE 2018). Satisfying the growing demand for energy, especially in the area of industry, transport and services, in accordance with energy policy for Poland is implemented by the further development of renewable energy sources (including solid biofuels, wind, solar, geothermal and biogas and hydro) and a gradual departure from fossil fuels (Policy 2009).

The domestic development of energy based on renewable energy sources is in line with the objectives of reducing the impact of energy on the environment, as well as increasing the country's energy security while maintaining the principle of the sustainable development (Policy 2009). Reducing the impact of energy on the environment is achieved by reducing $\mathrm{CO}_{2}, \mathrm{SO}_{2}$, $\mathrm{NO}_{\mathrm{X}}$, dust (including PM10 and PM2.5), protecting water resources, or minimizing the storage of waste from the combustion of fossil fuels (Policy 2009). The planned Polish Energy Policy until 2040 assumes the continuation of the current activities and the further increase in the share of renewable energy sources in the Polish energy mix (increase to $21 \%$ RES in the final gross energy consumption in 2030), as well as the reduction of electricity production from coal to $60 \%$ in 2014 (Policy 2018).

The use of solid biofuels, as zero-emission fuel, affects the reduction of electricity and heat production costs (Forum-energii.eu). Acquiring them for energy purposes influences the development of local resources, and thus also for the development of the local communities (Directive 2009).

According to the assumptions of the energy policy, the production of electricity from RES in 2020 was to be implemented from wind energy (44\%) and from biomass (33\%) (Policy 2009). Data regarding the actual production of electricity from RES for the period 2016-2017 indicate a departure from the above assumptions, as electricity generated from RES in 2016 was 55\%, and in $2017-62 \%$ (Open data 2019). The amount of electricity from renewable energy produced from biomass in the same period amounted to - 35\% in 2016 and 27\% in 2017 (Open data 2019). The decline in the share of biomass in RES energy production in Poland in recent years is due to the collapse of the support system (Forum-energia.eu; Olsztyńska 2017).

The development of renewable energy sources in the area of domestic heat engineering is still very slow, which results from insufficient financial resources allocated for the modernization of local heating plants. In 2017 , only $7.6 \%$ of heat was generated from renewable energy sources (URE 2018). It follows that the energy policy of the country in the area of heating is implemented with a long delay. This is of great importance in the area of shaping the structure of 
energy production from renewable energy sources, which is mainly produced in the area of large professional power engineering.

In connection with the above, the current use of biomass in the fuel mix of the domestic energy and heating sector is limited due to:

1) the collapse in recent years of the system for supporting the production of electricity from biomass;

2) periodic low coal prices, especially for installations co-burning biomass with coal;

3) undercapitalization of local district heating in the scope of carrying out necessary modernizations, including changes in energy carriers.

Opportunities for increased use of biomass for energy purposes are:

1) legal requirements of the European Union regarding the need to modernize heating and power facilities in order to reduce the level of pollution to the environment (the MCP and the IED directives);

2) increase in prices of $\mathrm{CO}_{2}$ emission rights required, among others when burning fossil fuels;

3) increase in public awareness in the area of air cleanliness and the need to reduce emissions of pollutants into the environment;

4) new European Union guidelines in the field of increasing the role of renewable energy in heating and cooling, which will apply in the Member States as of 2021 (Directive 2018);

5) co-financing programs for modernization in the area of heating by the National Fund for Environmental Protection and Water Management and operational programs from the European Union funds, which have appeared since 2018.

\section{References}

Act on renewable energy sources of 20 February 2015, Dz.U. 2015 item 478, as amended.

Act amending the act on renewable energy sources and some other acts of June 7, 2018, Dz.U. 2018 item 1276.

CZOPEK, P. 2014. Planned regulations regarding the production of energy from renewable sources, with particular emphasis on micro and small installations (presentation). Conference at the AGROTECH fair on March 7, 2014, Kielce.

Directive 2009/28/EC of the European Parliament and of the Council of 23.04.2009 on the promotion of the use of energy from renewable sources, amending and subsequently repealing Directives 2001/77/ EC and 2003/30/EC, Dz.U. UE L 140/16-62 from 05.06.2009.

Directive of the European Parliament and of the Council 2018/2001 of 11.12.2018 on the promotion of the use of energy from renewable sources, U. UE L 328/82 from 21.12.2018.

Directive 2010/75/EU of the European Parliament and of the Council of 24.11.2010 on industrial emissions, Dz.U. UE L 334/17 from 17.12.2010.

Directive 2015/2193 of the European Parliament and of the Council of 25.11.2015 on the limitation of emissions of certain pollutants into the air from medium combustion plants, Dz.U. UE L 313/1 from 28.11.2015.

Eurostat 2018. Energy, Transport and Environment Indicators, Statistical Book. 
Forecast of demand for fuels and energy until 2030, Annex 2 to "Poland's energy policy until 2030" from 10.11.2009, Ministry of Economy, Warsaw.

Forum-energii.eu 2018. Energy transformation in Poland. [Online] https://forum-energii.eu/pl/analizy/polska-transformacja-energetyczna [Accessed: 12.07.2019].

GUS 2017. Energy from renewable sources in 2016, Warsaw.

GUS 2018. Energy 2018, CSO Production Department, Warsaw.

Hryniewicz, M. and GrZYBEK, A. 2017. Surplus straw available for use energy in 2016. Problems of Agricultural Engineering (VII-IX): z. 3 (97), Institute of Technology and Life Sciences in Falenty, Falenty.

IEA 2016. Energy Policies of IEA Countries. Poland. International Energy Agency. [Online] www.iea.org [Accessed: 12.07.2019].

Information from the President of URE No. 75/2017 of 18.10 .2017 on the implementation of the ban on the use of wood other than energy wood, referred to in art. 2 point $7 \mathrm{a}$ of the Act on renewable energy sources for generating electricity in renewable energy installations indicated in the Act, the Energy Regulatory Office, Warsaw.

Information from the President of URE No. 61/2018 of 27.07.2018 on changing the definition of energy wood. Energy Regulatory Office, Warsaw.

KOBIZE (2012), Guidelines. Regulation on monitoring and reporting - guidelines on biomass issues in the EU ETS. IEP-NRI, Warsaw.

MirowsKi et al. 2018 - Mirowski, T., Mokrzycki, E., Filipowicz, M. and Sornek, K. 2018. Characteristics of selected biomass energy production technologies in distributed energy. Scientific journals of the Institute for Mineral Resources and Energy, Polish Academy of Sciences, Kraków, DOI: $10.24425 / 124387$

MoLO, B. 2016. European Union policy and the development of renewable energy sources in Germany. Yearbook of European Integration, Wrocław.

OLSZTYŃSKA, I. 2017 Turbulence on the biomass market. Kurier Drzewny Vol. 1/2017. [Online] https:// ksub.info/wp-content/uploads/2017/02/Kurier_Drzewny_012017.pdf [Accessed: 12.07.2019].

OLSZTYŃSKA, I. 2018. Factors shaping the domestic potential of solid biofuels. Scientific journals of the Institute for Mineral Resources and Energy, Polish Academy of Sciences, Kraków, DOI: 10.24425/124355.

Open data. Polish power industry. [Online] https://dane.gov.pl/dataset/1199/resource/14648 [Accessed: 12.07.2019].

Polish energy policy until 2030, adopted by the Council of Ministers on 10.11.2009, Ministry of Economy, Warsaw.

Poland's energy policy until 2040, PEP project v. 1.2 of 23.11.2018, Ministry of Energy, Warsaw.

PSE (Polish Energy Networks) (2018), KSE 2018 Report. Summary of quantitative data on the functioning of the National Power System in 2018. [Online] https://www.pse.pl/dane-systemowe/ funkcjonowanie-rb/raporty-roczne-z-funkcjonowania-kse-za-rok/raporty-za-rok-2018 [Accessed: 12.07.2019].

RATAJCZAK, E. and BIDZIŃSKI, G. 2013. Wood biomass market for energy purposes - economic and social aspects. Forest biomass for energy purposes. [In:] Gołos P. and Kaliszewski A. (ed.), Forest biomass for energy purposes. Forest Research Institute, Sękocin Stary.

Regulation of the Minister of Economy of 18 October 2012 on the detailed scope of obligations to obtain and submit for cancellation of certificates of origin, pay a replacement fee, purchase of electricity and heat generated in renewable energy sources and the obligation to confirm data on the amount of electricity produced in a renewable energy source . Dz.U. of 2012 item 1229, as amended.

Regulation of the Minister of the Environment of 22 April 2011 on emission standards for installations. OJ from 2011 No. 95 item 558 with later changes. 
SZCZUKOWSKI, S. and STOLARSKI, M. 2013. Plantations of fast-growing trees and shrubs as an alternative to biomass from the forest - current status, opportunities and threats to development. [In:] Gołos P. and Kaliszewski A. (ed.), Forest biomass for energy purposes. Forest Research Institute, Sękocin Stary.

UliAsZ-BocheŃCZYK, A. and MoKRZYCKI, E. 2015. Biomass as fuel in energy. Rocznik Ochrony Środowiska Vol. 17, Koszalin.

ZAJĄCZKOWSKI, S. 2013. Forecasts for logging in Poland in the perspective of 20 years and the possibility of using them to estimate wood resources for energy purposes. [In:] Gołos P. and Kaliszewski A. eds., Forest biomass for energy purposes. Forest Research Institute, Sękocin Stary.

\section{Biomasa w polskim miksie paliw do energetyki i ciepłownictwa}

\section{Streszczenie}

W 2008 r. Unia Europejska przyjęła pakiet klimatyczno-energetyczny. Przewiduje on trzy najważniejsze cele do osiągnięcia do 2020 r. w zakresie energetyki, są to: redukcja o 20\% emisji gazów cieplarnianych, 20\% udział energii ze źródeł odnawialnych w całkowitym zużyciu energii w UE, zwiększenie o 20\% efektywności energetycznej UE. W związku z tym poszczególne kraje zobowiązane zostały do odchodzenia od kopalnych surowców energetycznych na rzecz wytwarzania energii z OZE. W zależności od możliwości każdego z krajów oraz rozwoju OZE, wyznaczono różne cele dla poszczególnych państw. Dla Polski cel udziału energii OZE w całkowitym zużyciu energii został ustanowiony na poziomie 15\% (Dyrektywa 2009).

Polityka energetyczna Polski do 2030 r. zawiera strategie państwa w zakresie realizacji zadań i celów w obszarze energetyki wynikających z potrzeby budowania krajowego bezpieczeństwa oraz regulacji UE. Wyzwania obecnej krajowej energetyki to m.in. wzrastające zapotrzebowanie na energię i realizacja międzynarodowych zobowiązań w obszarze ochrony środowiska i klimatu (Polityka 2009).

Współczesna energetyka krajowa charakteryzuje się wysokim udziałem paliw kopalnych, głównie węgla, w produkcji energii elektrycznej i ciepła, a udział OZE jest różny dla w poszczególnych technologiach i sektorach energetycznych.

Polska posiada znaczne zasoby naturalne, które stanowią źródło biomasy na cele energetyczne. W krajowym zużyciu biomasy dominują duże jednostki energetyczne, a udział ciepłowni jest wciąż nieznaczny (Olsztyńska 2018).

Celem artykułu jest analiza, w oparciu o dostępne dane oraz obserwacje własne autora, udziału biomasy w krajowej energetyce i ciepłownictwie, a także zdefiniowanie czynników wpływających na poziom zastosowania biomasy w obszarze polskiej energetyki.

SŁOWA KLUCZOWE: energetyka, ciepłownictwo, biopaliwa stałe, polityka energetyczna Polski, miks energetyczny 